\title{
Extractive composition and bioactivity of Uncaria acida and Uncaria glabrata wood
}

\author{
Masendra Masendra',2, Brandon Aristo Verick Purba', Lies Indrayanti ${ }^{3}$, Ganis Lukmandaru ${ }^{\circledast}$
}

Masendra M., Purba B.A.V., Indrayanti L., Lukmandaru G., 2021. Extractive composition and bioactivity of Uncaria acida and Uncaria glabrata wood. Ann. For. Res. 64(2): 20-32.

Abstract Uncaria acida (red bajakah) and Uncaria glabrata (white bajakah) belong to the liana woody species. Both are naturally cultivated in Indonesia, particularly in Kalimantan (Borneo) island. This study, aims to investigate the extractive composition of $U$. acida and $U$. glabrata wood considering that extracts from different lianas usually are used as anticancer drugs (breast cancer). The phenolic, alkaloid, and saponin contents were measured by colorimetric and GC-MS methods, while the antioxidant, antifungal, and cytotoxicity were investigated using DPPH, Phanerodontia chrysosporium (white-rot), and brine shrimp lethality tests, respectively. The results showed that the total tannins, phenols, and saponins in $U$. acida were higher compared to U. glabrata, while the total flavonoids, alkaloids, polysaccharides, and antioxidant activity was lower. The GC-MS analysis indicated the presence of aromatic compounds, fatty acids, and triterpenoids in both species. High concentration of phenols, alkaloids, saponins, fatty acids, and steroids are known to provide support in terms of antioxidant, cytotoxicity, and antifungal activities.

Keywords: wood extractive, antifungi, bajakah, phytomedicine, polyphenols.

Addresses: 'Department of Forest Products Technology, Faculty of Forestry, Universitas Gadjah Mada, Indonesia| ${ }^{2}$ Department of Bioresources Technology and Veterinary, Vocational College, Universitas Gadjah Mada, Indonesia| ${ }^{3}$ Department of Forestry, Faculty of Agriculture, Universitas Palangkaraya, Indonesia.

$๒$ Corresponding Author: Ganis Lukmandaru (glukmandaru@ugm.ac.id).

Manuscript received August 07, 2020; revised November 24, 2021; accepted November 24, 2021. 


\section{Introduction}

The huge biodiversity of tropical forests is partially attributed to the presence of lianas, a plant group that shares a similar growth strategy: to reach the forest canopy by climbing other plants as support (Schnitzer $\&$ Bongers 2002). Lianas have broad variety of species which consist of up to $45 \%$ of all lignocellulosic plant species in some areas (Uwalaka et al. 2021). Uncaria comprises a group of lianas from Rubiceae family, which is characterized by its "hook" utilized to climb other plants. Approximately, 34 species of Uncaria were discovered across the world, including Asia, Africa, and America (Ridsdale 1978, Quattrocchi 2000). Two species from this genus, namely Uncaria acida (Hunter) Roxb. and U. glabrata (Blume) DC., are growing naturally in Indonesia, and are also known locally, particularly in Kalimantan, as 'bajakah'.

Plants from Uncaria genus are deployed as traditional medicines in Indonesia, as well as in several other countries such as Japan and China (Imamura et al. 2011, Fujiwara et al. 2006). In Indonesia, Uncaria, as an ethnopharmacological plant, is used by ethnic group of Dayak in Borneo and Anak Rawa in Riau Provinces. Uncaria gambir is used as a traditional herbal drink by the Kerabat Dayaknese people in West Kalimantan against the stomachache and as typhus medicine by Wonokerto Community in Yogyakarta Special Province (Kuni et al. 2015, Utami et al. 2019, Nahdi \& Kurniawan 2019).

Bajakah extracts were reported to contain alkaloids, triterpenoids and phenolics (Slade et al. 2005, Salim et al. 2011, Pavei et al. 2012, Zhang et al. 2020). Different alkaloids, including 19-epi-ajmallicine, rauniticine, $14 \alpha$-hydroxyraunitine, uncarine A, glabratine, deoxycordifoline, and flavonoids termed $(+)$-catechin, were detected in the barks and leaves U. glabrata (Arbain et al. 1992, Arbain et al. 1993, Arbain et al. 1998). Antioxidant activities of other Uncaria species such as $U$. tomentosa, U. guianensis, and U. gambir have been reported (Sandoval et al. 2002, NavarroHoyos et al. 2018, Apea-Bah et al. 2009). The level of toxicity and the potential to be used as novel anticancer agents and anti-Alzheimer's disease have been also investigated (Azad et al. 2018, Xu et al. 2021).

Other studies have revealed various other pharmacologically applications of Uncaria species, and that's why U. acida and U. glabrata might also be of interest for their medicinal value. However, existing studies showed limited information concerning the chemical composition for the wood part. This study is, therefore, recorded as the first investigation on extractive composition of $U$. acida (red bajakah) and $U$. glabrata (white bajakah) wood species and on their bioactivities.

\section{Materials and Methods}

\section{Sample collection and extraction}

The stems (diameter 3-5 cm) of the lianas were collected from Hampangen Educational Forest, Palangkaraya University, Central Kalimantan (Borneo) Province (113 30'16" E and 1 ${ }^{\circ} 51^{\prime} 35^{\prime \prime}$ $\mathrm{S}, 35 \mathrm{~m}$ a.s.l.). The sites present a mean annual precipitation ranging from 2,776 to $3,393 \mathrm{~mm}$ and a mean annual temperature ranging from 23 to $32{ }^{\circ} \mathrm{C}$. After collection, the specimens were deposited at the Indonesian Institute of Science. Subsequently, the samples were powdered and successively extracted using n-hexane, methanol, and hot water in a Soxhlet apparatus for 6 hours. The resulting solution was then dried through a rotary evaporator and the results were expressed in percentage of dry samples.

\section{Total tannin content (TTC)}

The total tannin content was investigated according to Padmaja (1989). $0.1 \mathrm{ml}$ of the extract $(1000 \mathrm{ppm})$ was diluted with $7.5 \mathrm{ml}$ of distilled water followed by the addition of $0.5 \mathrm{ml}$ Folin Denis' reagent and $1 \mathrm{ml}$ 
sodium carbonate (35\%). Further dilutions were performed to obtain a $10 \mathrm{ml}$ volume. Subsequently, the sample reaction was nurtured at room temperature for $30 \mathrm{~min}$ and the absorbance was recorded at $760 \mathrm{~nm}$. The total tannin content was expressed as tannic acid equivalent (mg TAE/g sample).

\section{Total phenolic content (TPC)}

The TFC assessment was conducted according to Brighente et al. (2007), where $2 \mathrm{ml}$ of the sample $(1 \mathrm{mg} / \mathrm{ml})$ were mixed with $2 \%$ $\mathrm{AlCl}_{3} 6 \mathrm{H}_{2} \mathrm{O}$ solution in methanol. The reaction was maintained at $20{ }^{\circ} \mathrm{C}$ and the sample absorbance was recorded at $415 \mathrm{~nm}$. The results were expressed in quercetin equivalents (mg QE/g extract).

\section{Total polysaccharides (TP)}

The TP measurement protocol consists of $1 \mathrm{ml}$ of the extract (1000 ppm) mixed with $1 \mathrm{ml}$ phenol $(5 \%)$ and $5 \mathrm{ml}$ concentrated sulfuric acid (98\%). Subsequently, the reaction was then paused for 20 mins at room temperature and the sample absorbance was read at $490 \mathrm{~nm}$ in line with glucose standard. The measurement unit was specified as mg glucose equivalent per g sample of extract (DuBois et al. 1956).

\section{Total alkaloids content (TAC)}

The $1000 \mathrm{ppm}$ of the extract $(1 \mathrm{ml})$ reacted with a mixture of $1 \mathrm{ml}$ of $0.025 \mathrm{M} \mathrm{FeCl}_{3}, 0.5 \mathrm{M}$ $\mathrm{HCl}, 1 \mathrm{ml}$ of $0.05 \mathrm{M}$, and 1, 10-phenanthroline solution in ethanol. The mixture was nurtured for $30 \mathrm{~min}$ at $70{ }^{\circ} \mathrm{C}$, and the absorbance was read at $510 \mathrm{~nm}$. The quinine standard was utilized for the calibration of total alkaloid content (mg QnE/g sample) (Singh et al. 2004).

\section{Total saponin content (TSP)}

The total saponin content was documented from a previous reference (Makkar et al. 2007). $0.25 \mathrm{ml}$ of extract (1000 ppm), $8 \%$ of vanillin reagent, and $72 \%$ of sulphuric acid were reacted for $10 \mathrm{~min}$ at $60{ }^{\circ} \mathrm{C}$ temperature.
The sample was then cooled on ice for $4 \mathrm{~min}$ in order to stop the reaction and subsequently read at $544 \mathrm{~nm}$. Diosgenin standard was applied for total saponin calibration (mg DE/g sample).

\section{GC-MS Analysis}

The methanol extract was sylilated according to Wijayanto et al. (2015). The process was performed by dissolving $1 \mathrm{mg}$ of the sample in trimethylchlorosilane $(15 \mu \mathrm{l})$ and N,Obis (trimethylsilyl) acetamide $(85 \mu l)$. Subsequently, the sample was evaporated after $1 \mathrm{~h}$ of incubation and the dry extract was dispersed in $1 \mathrm{ml} \mathrm{MeOH}$. The $n$-hexane samples were prepared by direct injection. Meanwhile, the gas chromatography-mass spectrometry (GC-MS) data were collected using GCMS-QP 2010 (Shimadzu, Japan). The $1 \mu \mathrm{l}$ of sylilated sample and nonsylilated $n$-hexane extracts were injected into the GC-MS machine. The GC conditions include Rtx-5MS capillary column (30 m x $0.25 \mathrm{~mm}$ I.D. and $0.25 \mu \mathrm{m}$; GL Sciences, Tokyo, Japan); column temperature was from $70{ }^{\circ} \mathrm{C}(1 \mathrm{~min})$ to $290{ }^{\circ} \mathrm{C}$ at $5{ }^{\circ} \mathrm{C} / \mathrm{min}$ at a injection temperature of $270{ }^{\circ} \mathrm{C}$ Detection temperature was of $290{ }^{\circ} \mathrm{C}$ and acquisition mass range of 50 - 800 amu using helium as the carrier gas. The sample mass spectrum was compared to the NIST library. The peak relative method was applied to calculate detected compounds.

\section{DPPH scavenging activity}

Antioxidant activity evaluation was performed according to Baba \& Malik (2015). $0.1 \mathrm{ml}$ extract $(1000 \mathrm{ppm})$ of methanol reacted with $3 \mathrm{ml}$ of $0.1 \mathrm{mM}$ DPPH (1,1-diphenyl-2picrylhydrazyl). The reaction was incubated for 30 mins and the absorbance was measured at $517 \mathrm{~nm}$. The antioxidant activity was calculated by equation (1):

DPPH scavenged $(\%)=100 \times($ Ao-A 1$) /$ Ao 
where Ao is the blank absorbance and A1 represents the sample absorbance.

\section{Antifungal activity}

The antifungal activity was measured according to Lukmandaru (2013), employing Phanerodontia chrysosporium (white-rot). The wood samples were placed on the surface of $20 \mathrm{ml}$ potato dextrose agar (PDA; Aldrich, Germany) medium in Petri dishes. $1 \mathrm{~h}$ after the sample spreading, the fungi were inoculated. The blank was conducted without extract and the samples were separately observed in three replications. Also, the positive control of commercial biocide was applied and the growth inhibition was calculated using equation 2 :

Growth inhibition $(\%)=(\mathrm{A} 0-\mathrm{A} 1) / \mathrm{A} 0 \times 100$ (2) Where $\mathrm{A}=\pi \times(\mathrm{d} / 2)^{2}, \mathrm{~d}=$ diameter of sample growth, A0 is the blank growth inhibition and A1 represents sample growth inhibition. The $\mathrm{IC}_{50}$ was calculated as $50 \%$ of fungi inhibition.

\section{Brine shrimp lethality}

To predict cytotoxicity, brine shrimp lethality test with some modifications was conducted (Sarah et al. 2017). The Artemia salina cyst (Breeders $($ ) was hatched in artificial sea water ( $9 \mathrm{~g}$ of rock salt per 1 litre of water). After 24 hours of constant lightning and aeration, the nauplii were introduced in different culture media. The extracts were diluted to 10,000 $\mu \mathrm{g} / \mathrm{ml}$ concentration using dimethyl sulfoxide (DMSO) and $50 \mu \mathrm{l}, 5 \mu \mathrm{l}$, and $1 \mu \mathrm{l}$ of the resulting solutions were added consecutively to $5 \mathrm{ml}$ of artificial sea water containing 10 nauplii. After 24 hours, the percentage of dead nauplii and $\mathrm{LC}_{50}$ values were calculated. Negative controls were also applied using only DMSO, Positive controls were created with gallic acid in a similar procedure. The brine shrimp test was calculated from equation 3 :

Lethality rate $(\%)=(\mathrm{A} 0-\mathrm{A} 1) /(\mathrm{A} 0) \times 100$

Where A0 is lethality of negative control and A1 is the sample lethality. The LC50 was calculated as the concentration of the extract or fractions assumed to kill $50 \%$ of nauplii.

\section{Chemicals}

Quercetin, gallic and tannic acids, quinine, diosgenin, DPPH, TMCS (trimethylchlorosilane), BSA (N, O-bis (trimethylsilyl) acetamide), Folin-Ciocalteu, and Folin-Denis' reagents were purchased from Sigma-Aldrich (Germany). The fungicide product was acquired from Bioindustries, Yogyakarta, Indonesia. The active biocides were methylene bis thiocyanate and 2-thyocyanomethyl thiobenzothiazole.

\section{Statistical analysis}

Two-way ANOVA was used to determine the significance of species and solvent factor by employing SPSS software (IBM, USA) with a 95\% confidence level. The data showing significant variation were further analysed with Tukey HSD test. Correlations between parameters were evaluated using Pearson coefficient.

\section{Results}

\section{Extractive content}

Figure 1 shows the extraction content of the two studied liana woody species. The extractions were performed in $n$-hexane, methanol and hot water. The highest extractive content of $U$. acida was obtained in methanol (10.2\%), while the highest extractive content for $U$. glabrata was obtained in hot water (5.76\%). These conditions suggests that both samples contained mainly phenolics and sugars.

\section{Extractive composition}

Table 1 shows the extractive composition of $U$. acida and $U$. glabrata indicating the values of TTC, TPC, TFC, TP, TSP, and TAC. TTC, TPC, and TSC of MeOH of both species were larger compared to hot water extracts. For TAC and TP, only U. glabrata provided higher value in its $\mathrm{MeOH}$ extract. Meanwhile, the TP and TAC contents of $U$. acida $\mathrm{MeOH}$ extract were lower compared to hot water extract. By 
applying ANOVA test a significant variation in the interaction between the species and fraction was observed.

\section{GC-MS analysis}

Table 2 shows the secondary metabolites identified in $\mathrm{MeOH}$ extracts. The constituents of both species were dominated by aromatic compounds. The major phenolic compounds involved benzoic acid, hydroquinone, and fatty acids in the form of palmitic and tetradecanoic, while the alkaloid was represented by $2-(5-$ [1,3] dioxolan-2-yl-pentyl)-3-methylaziridine. Previous reports also included the benzoic acid and hydroquinone derivatives in the species of Cinamomiun verum and Terminalia arjuna (Kankeaw \& Masong 2015, Dutta et al. 2015). Moreover, the fatty acids (C16: 0) were detected in Uncaria tomentosa (Makoto et al. 2003). However, in the $n$-hexane extracts, the lianas were dominated by steroids and teriterpenoids i.e beta-sitosterol acetate and ursane-3,12-diol (Table 2).

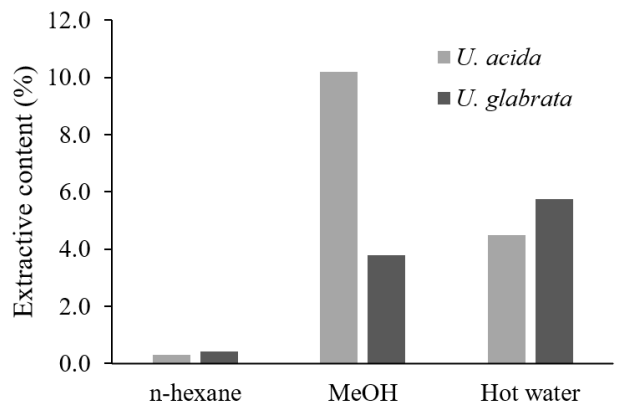

Figure 1 Extractive content of $U$. acida and $U$. glabrata woods

Table 1 Colorimetric measurement of $U$. acida and U. glabrata extracts.

\begin{tabular}{|c|c|c|c|c|c|c|c|}
\hline Sample & Fraction & $\begin{array}{c}\text { TTC } \\
\text { (mg TAE } / \mathrm{g})\end{array}$ & $\begin{array}{c}\text { TPC } \\
\text { (mg GAE/g) }\end{array}$ & $\begin{array}{c}\text { TFC } \\
(\mathrm{mg} \mathrm{QE} / \mathrm{g})\end{array}$ & $\begin{array}{c}\text { TP } \\
(\mathrm{mg} \mathrm{GE} / \mathrm{g})\end{array}$ & $\begin{array}{c}\text { TSC } \\
(\mathrm{mg} \mathrm{DE} / \mathrm{g})\end{array}$ & $\begin{array}{c}\text { TAC } \\
\text { (mg QnE/g) }\end{array}$ \\
\hline \multirow{2}{*}{ U. acida } & & & $166.5 \pm 1.83^{d}$ & $40.5 \pm 0.14^{\mathrm{c}}$ & $31.2 \pm 0.09^{\mathrm{b}}$ & $557.5 \pm 0.58^{d}$ & \\
\hline & & $239.5 \pm$ & $144.6=$ & $23.2 \pm 0$ & $5.9 \pm$ & $72.6 \pm 0$ & 120.3 \\
\hline \multirow{2}{*}{ U. glabrata } & & $244.9 \pm 0.3$ & $160.2 \pm 1.61^{\mathrm{c}}$ & $55.8 \pm 0.1$ & $119.8 \pm 1$ & $141.4 \pm 0.28^{c}$ & $117.6 \pm 0.20^{\mathrm{b}}$ \\
\hline & Hot water & $163.8 \pm 0.02^{\mathrm{a}}$ & $50.6 \pm 1.16^{\mathrm{a}}$ & $31.3 \pm 0.87^{\mathrm{b}}$ & $14.3 \pm 0.04^{\mathrm{a}}$ & $69.6 \pm 0.10^{\mathrm{a}}$ & $119.0 \pm 0.25^{\mathrm{c}}$ \\
\hline
\end{tabular}

Note:TTC/total tannin content $(\mathrm{p}<0.01) \mathrm{HSD}$ value $=0.12 ; \mathrm{TPC} /$ total phenolic content $(\mathrm{p}<0.01) \mathrm{HSD}$ value $=5.04$; TFC $/$ total flavonoid content $(\mathrm{p}<0.01) \mathrm{HSD}$ value=1.76; TP/total polysaccharides $(\mathrm{p}<0.01) \mathrm{HSD}$ value $=1.89$; TSC/total saponin content $(\mathrm{p}<0.01)$ HSD value $=1.37$; TAC/total alkaloid content $(\mathrm{p}<0.01)$ HSD value $=1.36$

Table 2 GC-MS results of MeOH (no. 1-16) and $n$-hexane (no. 17-23) extract from U. acida and U. glabrata.

\begin{tabular}{|c|c|c|c|c|c|}
\hline \multirow[t]{2}{*}{ No } & \multirow{2}{*}{$\begin{array}{l}\text { Ret. time } \\
\text { (min) }\end{array}$} & \multirow[t]{2}{*}{ Constituents } & \multicolumn{2}{|c|}{$\begin{array}{l}\text { Concentration } \\
\text { ( } \% \text { of dried extract) }\end{array}$} & \multirow{2}{*}{$\begin{array}{l}\text { Similarity } \\
\text { index }(\%\end{array}$} \\
\hline & & & U. acida & U. glabrata & \\
\hline & & Aromatics & 58.2 & 47.7 & \\
\hline 1 & 7.0 & Isopropyl vinyl & 2.3 & $\operatorname{tr}$ & 71 \\
\hline 2 & 7.1 & $\begin{array}{l}\text { (1S)-Propanol, (2S)-[(tert.butyloxycarbonyl)amino]- } \\
\text { 1-phenyl }\end{array}$ & 0.2 & $\operatorname{tr}$ & 60 \\
\hline 3 & 11.4 & Benzoic acid & 15.9 & 15.7 & 85 \\
\hline 4 & 12.5 & 4-Piperidinepropanoic acid, & 9.7 & 8.0 & 89 \\
\hline 5 & 12.9 & Hydroquinone & 10.2 & 6.0 & 81 \\
\hline 6 & 13.5 & 5-Hydroxymethylfurfural & 7.5 & 5.0 & 81 \\
\hline 7 & 16.3 & 2,4-Dimethoxyphenol & 5.9 & 1.0 & 81 \\
\hline 8 & 20.3 & Homovanillyl alcohol & 3.8 & 1.0 & 80 \\
\hline 9 & 22.3 & 2,2-Dimethyl-5-tert-butyl-1,3-oxathiane & 1.0 & 2.0 & 60 \\
\hline 10 & 22.5 & 2-(5-[1,3] Dioxolan-2-yl-pentyl)-3-methylaziridine & 1.7 & 9.04 & 60 \\
\hline
\end{tabular}


Table 2 GC-MS results of MeOH (no. 1-16) and n-hexane (no. 17-23) extract from U. acida and U. glabrata.

\begin{tabular}{|c|c|c|c|c|c|}
\hline \multirow{2}{*}{ No } & \multirow{2}{*}{$\begin{array}{l}\text { Ret. time } \\
\text { (min) }\end{array}$} & \multirow{2}{*}{ Constituents } & \multicolumn{2}{|c|}{$\begin{array}{c}\text { Concentration } \\
(\% \text { of dried extract) }\end{array}$} & \multirow{2}{*}{$\begin{array}{r}\text { Similarity } \\
\text { - index }(\%)\end{array}$} \\
\hline & & & U. acida & U. glabrata & \\
\hline & & Fatty acids & 41.5 & 46.8 & \\
\hline 11 & 27.4 & Tetradecanoic acid & 5.8 & 16.6 & 89 \\
\hline 12 & 28.1 & Palmitic acid & 26.3 & 20.2 & 90 \\
\hline 13 & 30.2 & 9,12-Octadecadienoic acid & 1.9 & 2.0 & 83 \\
\hline 14 & 30.9 & Stearolic acid & 4.1 & 3.0 & 84 \\
\hline \multirow[t]{2}{*}{15} & 31.3 & Nonadecanoic acid & 3.4 & 5.0 & 82 \\
\hline & & Steroids and triterpenoids & 67.5 & 77.8 & \\
\hline 16 & 42.2 & Stigmast-5-en-3-ol, oleate & 8.0 & $\operatorname{tr}$ & 60 \\
\hline 17 & 44.2 & beta-Sitosterol acetate & 59.5 & 38.9 & 72 \\
\hline 18 & 47.8 & Ergosta-4,6,22-trien-3.alpha.-ol & $\operatorname{tr}$ & 10.2 & 64 \\
\hline \multirow[t]{2}{*}{19} & 48.7 & Ursane-3,12-diol & - & 28.6 & 55 \\
\hline & & Other compounds & 31.5 & 21.8 & \\
\hline 20 & 14.2 & Cyclohexasiloxane, dodecamethyl- & 10 & 10 & 77 \\
\hline 21 & 18.2 & Nonane, 1-iodo- & 6.9 & - & 71 \\
\hline 22 & 18.9 & Hexamethyl-3,5,5-tris(trimethylsiloxy)tetrasiloxane & 14.6 & - & 79 \\
\hline 23 & 49.7 & $\begin{array}{l}\text { 3,4-Dimethylbenzoic acid, tert-butyldimethylsilyl } \\
\text { ester }\end{array}$ & - & 11.8 & 50 \\
\hline
\end{tabular}

Note:(tr): trace; (-): not detected

Bioactivities (antioxidant, antifungal, and cytotoxicity)

DPPH scavenging: The highest antioxidant activity was established in the $\mathrm{MeOH}$ extracts for U. glabrata and in hot water extracts for $U$. acida $(\mathrm{p}<0.01$; HSD value $=31.14)$. The values were higher in $U$. glabrata compared to the quercetin positive control (Fig. 2).

Antifungal activity: Table 3 shows the inhibition of $P$. chrysosporium of $U$. acida and $U$. glabrata extracts. Both species confirmed a weak fungal activity compared to biocide positive control.

Cytotoxicity: The last bioactivity for $U$. acida and U. glabrata was conducted by brine shrimp lethality test. In Table 4 is shown that the maximum cytotoxicity level occurred in $U$. glabrata $n$-hexane soluble extract, while the lowest activity is reflected in $\mathrm{MeOH}$ extract. However, the $n$-hexane and hot water of $U$. glabrata extracts citotoxicity were higher compared to gallic acid positive control. Generally, all the recorded values were moderate.

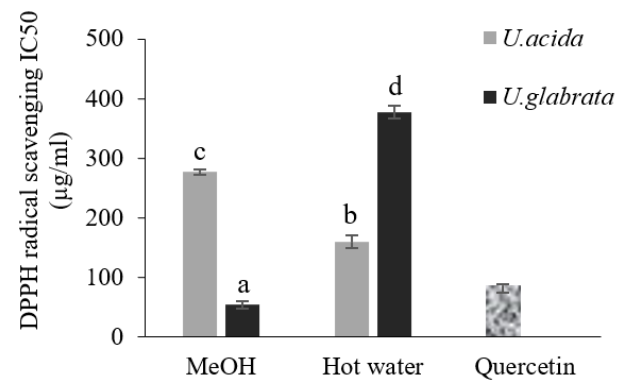

Figure 2 Antioxidant activity of $U$. acida and $U$. glabrata extracts.

\section{Correlation between parameters}

Table 5 shows the Pearson correlation between separate parameters. The highest negative value was obtained between TSC and TAC $(\mathrm{r}=-0.99 *)$, while the optimum positive rate 
Table $3 \mathrm{IC}_{50}$ of inhibitory activity of $P$. chrysosporium $(\mu \mathrm{g} / \mathrm{ml})$.

\begin{tabular}{ccccc}
\hline Sample & n-hexane & $\begin{array}{c}\text { Extract } \\
\text { MeOH }\end{array}$ & Hot water & Biocide \\
\hline U. acida & $>2000$ & $1901 \pm 117$ & $1561 \pm 345$ & $<500$ \\
U. glabrata & $>2000$ & $1569 \pm 140$ & $1758 \pm 401$ & \\
\hline
\end{tabular}

Table $4 \mathrm{LC}_{50}$ of brine shrimp test $(\mu \mathrm{g} / \mathrm{ml})$.

\begin{tabular}{ccccc}
\hline Sample & n-hexane & $\begin{array}{c}\text { Extract } \\
\text { MeOH }\end{array}$ & Hot water & $\begin{array}{c}\text { Gallic } \\
\text { acid }\end{array}$ \\
\hline U. acida & $138 \pm 36^{\mathrm{ab}}$ & $146 \pm 63^{\mathrm{ab}}$ & $159 \pm 51^{\mathrm{b}}$ & \\
U. glabrata & $31 \pm 0.1^{\mathrm{a}}$ & $248 \pm 54^{\mathrm{b}}$ & $90 \pm 13^{\mathrm{a}}$ & \\
\hline
\end{tabular}

occurred between TTC and TPC ( $\left.\mathrm{r}=0.98^{*}\right)$. Furthermore, strong negative correlations appeared between TP and TAC $(\mathrm{r}=-0.92 * *)$, DPPH and TPC $\left(\mathrm{r}=-0.71^{* *}\right)$, DPPH and TTC $\left(\mathrm{r}=-0.76^{* *}\right)$ as well as a strong positive correlation measured between TSC and TP $\left(\mathrm{r}=0.92^{* *}\right)$. Additional important correlations were also found between TP and TPC $\left(\mathrm{r}=0.65^{*}\right)$, TTC and TP $\left(\mathrm{r}=0.59^{*}\right)$, brine shrimp $\mathrm{LC}_{50}$, and TTC $(\mathrm{r}=0.59 *)$.

\section{Discussions}

The phenolic, alkaloids, and saponin contents of the samples were observed. Extractive composition was significantly influenced by solvent polarity and species variations. Generally, both species extracts were dominated by less polar compounds, apart from the TP and TPC of $U$. acida. Furthermore, the $U$. acida contained superior amounts of total saponins and phenolics, including tannins, whereas $U$. glabrata showed maximum concentration of total flavonoids, polysaccharides, and alkaloids. $U$. acida and $U$. glabrata have higher TPC and TFC levels than that of $U$. gambir (Kassim et al. 2011, Amir et al. 2012) and $U$. tomentosa (Navarro-Hoyos et al. 2015). However, both species have a lower content compared to the TPC and TFC levels of $U$. rhynchophylla.

The most noticeable dissimilarity between species occurred in the TSC value. Saponin is a glycoside compound containing aglycone (triterpenoid, steroid, or steroidal alkaloid) linked to glycone or oligosaccharide moieties (Mohan et al. 2016). Therefore, as a result of its high saponin content, $U$. acida is expected to be utilized in applications involving biopesticides, biosurfactants, and pharmaceuticals. However, the saponin compounds are harmful in general (Jiang et al. 2018). Due to the fact that previous research reported moderate toxicity of $U$. acida leaves extract (Azad et al. 2018) and due to the diversity of saponin structures in plants, the use of $U$. acida extracts requires further studies, before being deployed.

Table 5 Pearson correlation between DPPH and phytochemicals in U. acida and U. glabrata.

\begin{tabular}{|c|c|c|c|c|c|c|c|c|}
\hline Parameter & TAC & TPC & $\mathbf{T P}$ & TSC & TTC & TFC & $\begin{array}{c}\text { DPPH } \\
\text { IC }_{50}\end{array}$ & $\begin{array}{c}\text { Fungal } \\
\text { IC }_{50}\end{array}$ \\
\hline TPC & -0.45 & & & & & & & \\
\hline $\mathrm{TP}$ & $-0.92 * *$ & $0.65^{*}$ & & & & & & \\
\hline TSC & $-0.99 * *$ & 0.52 & $0.92 * *$ & & & & & \\
\hline TTC & -0.33 & $0.98 * *$ & $0.59 *$ & 0.40 & & & & \\
\hline TFC & -0.17 & 0.42 & 0.00 & 0.27 & 0.31 & & & \\
\hline DPPH IC50 & -0.27 & $-0.71 * *$ & 0.06 & 0.17 & $-0.76^{* *}$ & -0.51 & & \\
\hline Fungal IC50 & -0.43 & -0.08 & 0.32 & 0.41 & -0.13 & -0.02 & 0.39 & \\
\hline Brine shrimp LC50 & 0.13 & 0.48 & 0.19 & -0.11 & $0.59 *$ & -0.26 & -0.50 & -0.12 \\
\hline
\end{tabular}


The $\mathrm{MeOH}$ extract of $U$. glabrata exhibited a higher level of inhibition compared to hot water extract in terms of antioxidant activity (Figure 2). This is probably due to the presence of high total tannins, phenolics, and flavonoids content. The polyphenol is one of the antioxidant agents derived from plants with the ability to reduce DPPH into DPPH-H as a result of the presence of $-\mathrm{OH}$ bond. Previous study shows the existence of cathechins in this species (Arbain et al. 1993). This compound is assumed to exhibit antioxidant activity of $U$. glabrata methanol extract. However, various patterns are known to occur in $U$. acida and the hot water extract generated higher antioxidant activity compared to $\mathrm{MeOH}$. This indicates that the polyphenolic compound was bonded with sugars in the form of glycosides. The high concentration of total tannin and phenolic content in hot water extract also tend to cause the DPPH reduction. The antioxidant activity of $U$. acida and $U$. glabrata were in lower rate compared to $U$. gambir, the well-known Southeast Asia liana (Kassim et al. 2011) and the famous Chinese herbal of $U$. rhynchophylla (Kim et al. 2012).

Based on the GC-MS results, the two woody species contained high concentration of aromatic compounds known to promote antioxidant activity. In addition, the phenolic compounds i.e. benzoic acid and hydroquinone tend to act as DPPH inhibitors. Earlier studies reported that these derivatives were applied as efficient antioxidant agents (Velika \& Kron 2012, Kankeaw \& Masong 2015). The presence of these aromatic compounds also was detected in other lianas, i.e. U. gambir (Navarro-Hoyos et al. 2015) and $U$. rhynchophylla (Zhang et al. 2016).

The antifungal activity of the lianas on $P$. chrysosporium showed that the $\mathrm{MeOH}$ and hot water extracts exhibited stronger inhibition compared to n-hexane. This indicated the presence of the more polar compounds in the extracts. The phenolic compounds also tend to hinder the fungal activity. Previously, white- rot fungi inhibitors, i.e., lignan and latifolin, were reported as having antifungal activity (Sekine et al. 2009, Wijayanto et al. 2015). Therefore, the presence of phenol contents as well as aromatic compounds in $U$. acida and U. glabrata is assumed to be responsible for the $P$. chrysosporium inhibition. Furthermore, the fungal growth inhibitory potential of lianas was also studied using species such as $U$. gambir (Nandika et al. 2019) and U. tomentosa (Moraes et al. 2015).

Variation in recorded antioxidant and antifungal activity indicated that the cytotoxicity of $U$. acida and $U$. glabrata $n$-hexane extracts is the highest. In addition, the compounds were assumed to be responsible for the brine shrimp lethality due to the fact that n-hexane contained more steroids and triterpenoids. This represents a lower lethality rate of $U$. acida wood extracts compared to its leaves (Azad et al. 2018) and hooks of $U$. tomentosa (Sofiana et al. 2020) but brine shrimp lethality levels of both $U$. acida and $U$. glabrata were higher than of $U$. cordata leaves (Azad et al. 2018) and U. rhynchophylla hooks (Orlando et al. 2019).

The correlation of the compound type plays a significant role in bioactivity. In this study, two phenolic types, termed TPC and TTC, were compared with DPPH $\mathrm{IC}_{50}$. A lower $\mathrm{IC}_{50}$ value reflected a stronger antioxidant activity. Meanwhile, a negative correlation indicates a positive interaction between the compound and the antioxidant activity. The role of phenolics as antioxidants has been previously reported (Zeka et al. 2019). Similarly, previous study related to $U$. tomentosa, reported a correlation between TPC and antioxidant activity (NavarroHoyos et al. 2018). This research identified the highest correlation with antioxidant activity using TTC. The result showed the antioxidant activity is attributed to the tannin compound in both species. Furthermore, correlation between antioxidant activity and tannin content also was recorded in an earlier report (Bizuayehu et al. 2015). No correlation of the TAC type agreed with previous research by Sandoval 
et al. (2002), where the result of antioxidant activity from $U$. tomentosa and $U$. guianensis have not been correlated with their alkaloid content.

This experiment revealed a significant positive correlation between $\mathrm{LC}_{50}$ and TTC, indicating a negative correlation between toxicity and TTC. Tannin compounds are known to possess toxic effects due to the ability to reduce nutrient digestibility and protein availability (Mena et al. 2015). However, the tannin ingestion had also been reported to enhance the organism's survival rate such as of Morone saxatilis larvae (Ashraf \& Bengtson 2007). The tannin toxicity was also described as dependent to its type and molecular sizes, where gallotannin was recorded to be more toxic than ellagitannin to $A$. salina nauplii (Yamasaki et al. 2002). This result indicates the toxicity of $U$. acida and $U$. glabrata were not attributed to its tannin compound.

Several correlations between compounds measured by colorimetric assay were also established, although this study measured TP and TTC. Hydrolysable tannins are polyesters of organic acids and polysaccharides (Plaza et al. 2018). This correlation tends to indicate the presence of polysaccharides in the tannin group. Furthermore, a correlation between TPC and TTC indicates tannin as a dominant compound in the phenolic group, while flavonoids being the less dominant. Some saponin compounds can be classified as steroidal alkaloid saponins containing steroidal alkaloid as its aglycone (Rahman \& Choudhary 1999). The negative correlation between TAC and TSC is interpreted as the absence of steroidal alkaloids saponin in the extract.

\section{Conclusion}

The chemical extracts of $U$. acida and $U$. glabrata were investigated for the first time by colorimetric and GC-MS methods. For both species, the extracts contained phenols, alkaloids, and saponins. The GC-MS studies also confirmed that both species contained phenolic compounds, alkaloids, fatty acids, steroids and triterpenoids. Concerning the antioxidant activity, the highest antioxidant activity and lethality rate of brine shrimp occurred in $U$. glabrata when compared to $U$. acida. In summary, the enhanced phenol contents and aromatic compounds contained in bajakah suggested that these chemicals contribute to the antioxidant and antifungal activities whereas the high levels of steroids and triterpenoids are responsible for their cytotoxicity. Therefore, the $U$. acida and $U$. glabrata or bajakah wood may potentially act as phytomedicines.

\section{Acknowledgment}

We thank to Indonesian Institute of Science for identification of the leaf specimens.

\section{References}

Adwas A.A., Elsayed A.S.I., Azab A.E., Quwaydir F.A., 2019. Oxidative stress and antioxidant mechanisms in human body. MedCrave 6(1): 43-47. https://doi. org/10.15406/jabb.2019.06.00173

Amir M., Mujeeb M., Khan A., Ashraf K., Sharma D., Aqil M., 2012. Phytochemical analysis and in vitro antioxidant activity of Uncaria gambir. International Journal of Green Pharmacy 6: 67-72. https://doi. org/10.4103/0973-8258.97136

Apea-Bah F.B., Hanafi M., Dewi R.T., Fajriah S., Darmawan A., et al. 2009. Assessment of the DPPH and $\alpha$-glucosidase inhibitory potential of gambier and qualitative identification of major bioactive compound. Journal of Medicinal Plants Research 3: 736-757.

Arbain D., Byrne L.T., Magda M.P., Sargent M.V., Syarif M., 1992. A new glucoalkaloid from Uncaria glabrata. Journal of the Chemical Society, Perkin Transactions 1: 665-666.

Arbain D., Afrida, Sargent M.V., Skelton B.W., White A.H., 1998. The alkaloids of Uncaria cf. glabrata. Australian Journal of Chemistry 51: 961-964. https:// doi.org/10.1071/C98078

Arbain D., Putri M.M., Sargent M.V., Syarif M., 1993. The alkaloids of Uncaria glabrata. Australian Journal of Chemistry 46: 863-872. https://doi.org/10.1071/ CH9930863

Ashraf M, Bengtson D.A., 2007. Effect of tannic acid on feed intake, survival and growth of striped bass (Morone saxatilis) larvae. International Journal of Agriculture \& Biology 9(5): 751-754.

Azad A.K., Jainul M.A., Labu Z.K., 2018. Cytotoxic activity on brine shrimp, MCF-7 cell line and 
thrombolytic potential: seven different medicinal plant leaves extract. Journal of Scientific Research 10(2): 175-178. https://doi.org/10.3329/jsr.v10i2.34820

Baba S.A., Malik S.A., 2015. Determination of total phenolic and flavonoid content, antimicrobial and antioxidant activity of a root extract of Arisaema jacquemontii Blume. Journal of Taibah University for Science 9(4): 449-454. https://doi.org/10.1016/j. jtusci.2014.11.001

Bizuayehu D., Atlabachew M., Ali M.T., 2016. Determination of some selected secondary metabolites and their invitro antioxidant activity in commercially available Ethiopian tea (Camellia sinensis). SpringerPlus 5: 1-9. https://doi.org/10.1186/s40064-016-2056-1

Brighente I.M.C., Dias M., Verdi L.G., Pizzolatti M.G., 2007. Antioxidant activity and total phenolic content of some Brazilian species. Pharmaceutical Biology 45(2): 156-161. https://doi.org/10.1080/13880200601113131

Diouf P.N., Stevanovic T., Cloutier A., 2009. Antioxidant properties and polyphenol contents of Trembling aspen bark extracts. Wood Science Technology 43(4): 457470. https://doi.org/10.1007/s00226-009-0240-y

Duarte T.L., Lunce J., 2005. Review: When is an antioxidant not an antioxidant? A review of novel actions and reactions of vitamin C. Free Radical Research 39(7): 671-686. https://doi.org/10.1080/10715760500104025

DuBois M., Gilles K.A., Hamilton J.K., Rebers P.A., Smith F., 1956. Colorimetric method for determination of sugars and related substances. Analytical Chemistry 28(3): 350-356. https://doi.org/10.1021/ac60111a017

Dutta M., Chattopadhyay A., Ghosh A.K., Chowdhury U.R., Bhowmick D., et al. 2015. Benzoic acid, one of the major components of aqueous bark extract of Terminalia arjuna protects against CopperAscorbate induced oxidative stress in human placental mitochondria through antioxidant mechanism(s): an in vitro study. Journal of Pharmacy Research 9(1): 64-88.

Fujiwara H., Iwasaki K., Furukawa K., Seki T., He M., et al. 2006. Uncaria rhynchophylla, a Chinese medicinal herb, has potent antiaggregation effects on Alzheimer's betaamyloid proteins. Journal of Neuroscience Research 84: 427-433. https://doi.org/10.1002/jnr.20891

Halliwell B., 2007. Biochemistry of oxidative stress. Biochemistry Society Transactions 35: 1147-1150.

Imamura S., Tabuchi M., Kushida H., Nishi A., Kanno H., et al. 2011. The blood - brain barrier permeability of geissoschizine methyl ether in Uncaria hook, a galenical constituent of the traditional Japanese medicine Yokukansan. Cellular and Molecular Neurobiology 31: 787-793. https://doi.org/10.1007/s10571-011-9676-3

Jiang X., Cao Y., Jørgensen L.G., Strobel B.W., Hansen H.C.B., Cedergreen N., 2018. Where does the toxicity come from in saponin extract? Chemosphere 204: 243-250. https://doi.org/10.1016/j. chemosphere.2018.04.044

Kankeaw U., Masong K., 2015. The antioxidant activity from hydroquinone derivatives by the synthesis of Cinnamomium verum J.Presl bark's extracted.
International Journal of Chemical Engineering and Applications 6(2): 91-94. https://doi.org/10.7763/ IJCEA.2015.V6.458

Kassim M.J., Hussin M.H., Achmad A., Dahon N.H., Suan T.K., Hamdan H.S. 2011. Determination of total phenol, condensed tannin and flavonoid contents and antioxidant activity of Uncaria gambir extracts. Majalah Farmasi Indonesia 22(1): 50-59. http://dx.doi. org/10.14499/indonesianjpharm0iss0pp50-59

Kim Y., Hwang J., Kim S., Kim E., Jeon Y., Moon S., Jeon B., Park P., 2012. Antioxidant activity and protective effects of Uncaria rhynchophylla extracts on t-BHPinduced oxidative stress in chang cells. Biotechnology and Bioprocess Engineering 17: 1213-1222. https://doi. org/10.1007/s12257-012-0278-9

Kuni B.E., Hardiansyah G., Idham, 2015. Ethnobotany of Dayak Kerabat tribe in the Tapang Perodah village subdistrict of Sekadau Hulu the district of Sekadau. Jurnal Hutan Lestari 3(3): 383-400. http://dx.doi.org/10.26418/ jhl.v3i3.11211

Lukmandaru G., 2013. Antifungal activities of certain components of teak wood extractives. Jurnal Ilmu Teknologi Kayu Tropis 11(1): 11-18.

Makkar H.P.S.; Siddhuraju P., Becker K., 2007. Molecular Biology: Plant secondary metabolites. 1st Edition, Humana Press Inc., Totowa, New Jersey, USA, pp. 93100 .

Makoto O., Yoshimichi F., Fumio T., Shingo I., 2003. Fatty Acid Compositions of Lipids in Cat's Claw (Uncaria tomentosa) and Maca (Lepidium meyenii). Food Preservation Science 29(1): 37-40.

Mena P., Calani L., Bruni R., Rio D.D., 2015. Bioactivation of high-molecular-weight polyphenols by the gut microbiome. In: Diet-microbe interactions in the gut; Effects on human health and disease. Tuohy K., Rio D.D. (eds.). Academic Press, London. https://doi. org/10.1016/B978-0-12-407825-3.00006-X

Mohan V.R., Tresina P.S., Daffodil E.D., 2016. Antinutritional factors in legume seeds: characteristics and determination. In: Encyclopedia of Food and Health. Caballero B., Finglas P.M., Toldrá F. (eds.). Academic Press, Oxford. https://doi.org/10.1016/B9780-12-384947-2.00036-2

Moraes R.C., Lana A.J.D., Kaiser S., Carvalho A.R., De Oliveira L.F.S., et al. 2015. Antifungal activity of Uncaria tomentosa (Wild.) D.C. against resistant nonalbicans Candida isolates. Industrial Crops and Products 69: 7-14. https://doi.org/10.1016/j.indcrop.2015.01.033

Nahdi M.S., Kurniawan A.P., 2019. The diversity and ethnobotanical study of medicinal plants in the southern slope of Mount Merapi, Yogyakarta, Indonesia. Biodiversitas 20(8): 2279-2287. https://doi. org/10.13057/biodiv/d200824

Nandika D., Syamsu K., Ariana, Kusumawardhani D.T., Fitriamna., 2019. Bioactivities of catechin from gambir (Uncaria gambir Roxb.) against wood-decaying fungi. BioResources 14(3): 5646- 5656. https://doi. org/10.15376/biores.14.3.56646-5656 
Navarro-Hoyos M., Alvarado-Corella D., MoreiraGonzalez I., Arnaez-Serrano E., Monagas-Juan M., 2018. Polyphenolic composition and antioxidant activity of aqueous and ethanolic extracts from Uncaria tomentosa bark and leaves. Antioxidants 7(5): 65 . https://doi.org/10.3390/antiox7050065

Navarro-Hoyos M., Sanchez-Patan F., Masis R.M., Martin-Alvarez P., Ramirez W.Z., et al. 2015. Phenolic assessment of Uncaria tomentosa L. (Cat's claw): leaves, stem, bark, and wood extracts. Molecules 20: 2270322717. https://doi.org/10.3390/molecules201219875

Orlando G., Chiavaroli A., Leone S., Brunetti L., Politi M., et al. 2015. Inhibitory effects induced by Vicia faba, Uncaria rhyncophylla, and Glyrrhiza glabra water extracts on oxidative stress biomarkers and dopamine turnover in HypoE22 cells and isolated rat striatum challenged with 6-hydroxydopamine. Antioxidants 8(602): 1-14. https://doi.org/10.3390/antiox8120602

Padmaja G., 1989. Evaluation of techniques to reduce assay-able tannin and cyanide in cassava leaves. Journal Agriculture Food and Chemistry 37: 712-716. https:// doi.org/10.1021/jf00087a029

Pavei C., Kaiser S., Verza S.G., Borre G.L., Ortega G.G., 2012. HPLC-PDA method for quinovic acid glycosides assay in Cat's claw (Uncaria tomentosa) associated with UPLC/Q-TOF-MS analysis. Journal of Pharmaceutical and Biomedical Analysis 62: 250-257. https://doi. org/10.1016/j.jpba.2011.12.031

Plaza M., Domínguez-Rodríguez G., Castro-Puyana M., Marina M.L., 2018. Polyphenols analysis and related challenges. In: Polyphenols: Properties, Recovery, and Applications (Galanakis C.M. ed.). Woodhead Publishing: Austria.

Quattrocchi U., 2000. CRC World dictionary of plant names. Volume IV. CRC Press: Boca Raton; New York; Washington DC; USA. London, UK.

Rahman A.U., Choudhary M.I., 1999. Chemistry and biology of steroidal alkaloids from marine organisms. In: The Alkaloids: Chemistry and Biology (Cordell, G.A. ed.). Academic Press: California. 391 p. https:// doi.org/10.1016/S1099-4831(08)60040-1

Ridsdale C.E., 1978. A revision of Mytragyna and Uncaria (Rubiaceae). Blumea 24: 43-100.

Salim F., Ismail N.H., Awang K., Ahmad R., 2011. Rauniticine-allo-oxindole $\mathrm{B}$ and rauniticinic-allo acid B, new heteroyohimbine-type oxindole alkaloids from the stems of Malaysian Uncaria longiflora var. pteropoda. Molecules 16: 6541-6548. https://doi.org/10.3390/ molecules 16086541

Sandoval M., Okuhama N.N., Zhang XZ., Condezo L.A., Lao J., et al. 2002. Anti-inflammatory and antioxidant activities of cat's claw (Uncaria tomentosa and Uncaria guianensis) are independent of their alkaloid content. Phytomedicine 9(4): 325-337. https://doi. org/10.1078/0944-7113-00117

Sarah Q.S., Anny F.C., Misbahuddin M., 2017. Brine shrimp lethality assay. Bangladesh Journal of Pharmacology 12(2): 186-189. https://doi.org/10.3329/ bjp.v12i2.32796

Schnitzer S.A., Bongers F., (2002). The ecology of lianas and their role in forests. Trends in Ecology and Evolution 17: 223-230. https://doi.org/10.1016/S01695347(02)02491-6

Sekine N., Ashitani T., Murayama T., Shibutani S., Hattori S., Takahashi K., 2009. Bioactivity of latifolin and its derivatives against termites and fungi. Journal of Agriculture Food Chemistry 57: 5707-712. https://doi. org/10.1021/jf900719p

Singh D.K., Srivastva B., Sahu A., 2004. Spectrophotometric determination of Rauvolfia alkaloids, estimation of reserpine in pharmaceuticals. Analytical Science 20: 571-573. https://doi.org/10.2116/analsci.20.571

Slade D., Ferreira D., Marais J.P.J., 2005. Circular dichroism, a powerful tool for the assessment of absolute configuration of flavonoids. Phytochemistry 66: 2177 2215. https://doi.org/10.1016/j.phytochem.2005.02.002

Sofiana M.J., Warsidah, Iskandar D., 2020. Cytotoxicity activities of ethanol extract of hooks Uncaria tomentosa West Kalimantan. The Journal of Food and Medicinal Plants 1(1): 1-4. https://doi.org/10.25077/jfmp.1.1.14.2020

Utami R.D., Zuhud E.A.M., Hikmat A., 2019. Medicinal ethnobotany and potential of medicine plants of Anak Rawa ethnic at the Penyengat village Sungai Apit Siak Riau. Media Konservasi 24(1): 40-51. https://doi. org/10.29244/medkon.24.1.40-51

Uwalaka N.O., Borisade T.V., Rufai A.B., 2021. Liana abundance and colonization in a tropical moist secondary lowland rainforest in Nigeria. Taiwania 66(2): 174-183. https://doi.org/10.6165/tai.2021.66.174

Velika B., Kron I., 2012. Antioxidant properties of benzoic acid derivatives against superoxide radical. Free Radicals and Antioxidants 2(4): 62-67. https://doi. org/10.5530/ax.2012.4.11

Wijayanto A., Dumacay S., Gerardin-Charbonnier C., Sari R.K, Syafii W., Gerardin P., 2015. Phenolic and lipophilic extractives in Pinus merkusii Jungh. et de Vries knots and stemwood. Industrial Crops and Products 69: 466471. https://doi.org/10.1016/j.indcrop.2015.02.061

Xu Q.Q., Shaw P.C., Hu Z., Yang W., Ip S.P., et al. 2021. Comparison of the chemical constituents and antiAlzheimer's disease effects of Uncaria rhynchophylla and Uncaria tomentosa. Chinese Medicine 16: 110. https://doi.org/10.1186/s13020-021-00514-2

Yamasaki T., Sato M., Mori T., Mohamed A.S.A., Fuiji K., Tsukioka J., 2002. Toxicity of tannins towards the freeliving nematode Caenorhabditis elegans and the brine shrimp Artemia salina. Journal of Natural Toxins 11(3): 165-171.

Zeka K., Alfa H.H., Ruparelia K.C., Arroo R.R.K., 2019. Use of natural products in the prevention and management of type 2 diabetes. Studies in Natural Products Chemistry 63: 197-210. https://doi. org/10.1016/B978-0-12-817901-7.00007-1

Zhang J.G., Huang X.Y., Ma Y.B., Chen J.J., Geng C.A., 2020. UFLC-PDA-MS/MS profiling of seven Uncaria 
species integrated with melatonin/5-hydroxytryptamine receptors agonistic assay. Natural Products and Bioprospecting 10: 23-36. https://doi.org/10.1007/ s13659-020-00230-8

Zhang Q., Chen L., Hu L., Liu W., Feng F., Qu W., 2016. Two new ortho benzoquinones from Uncaria rhyncophylla. Chinese Journal of Natural Medicines 14(3): 232-235. https://doi.org/10.1016/S18755364(16)30021-8 